\title{
Contributions to the Comparative Anatomy of some British Actiniæ.
}

\author{
By \\ Olwen M. Rees, B.Sc., \\ Zoological Department, University College of Wales, Aberystuyth.
}

With Figures 1-16 in the Text.

THE main object of this paper is to give a comparative anatomical description of some British Anemones as well as to describe each individually; but the account is not so full as it was expected to be, as it was not possible to get all the species required.

In most cases the specimens were examined externally before sections were cut. Each specimen was prepared according to the usual method used with paraffin wax, and I found during the progress of the work that borax carmine was the stain which gave the most satisfactory results.

I should like to thank Miss E. de Fraine, D.Sc., Mr. F. W. Durlacher, and Mr. F. S. Wright for much assistance in the course of the work.

For specimens collected and sent I am deeply indebted to Dr. E. J. Allen and his staff at Plymouth, Miss Delap, of Valentia Island, and Monsieur Louis Fage, of the Laboratoire Arago, Banyuls-sur-Mer, France.

\section{FAM. SAGARTID正 (Gosse, 1858).}

"Actiniinæ with a contractile pedal disk; body-wall smooth, or provided with verrucæ or tubercles, and usually perforated with cinclides, with or without a cuticle. Tentacles usually numerous and retractile, not very long, smooth, simple and generally entacmæous, sphincter muscle characteristically well developed and mesogloeal, occasionally diffuse endodermal, or even absent. At least six pairs of mesenteries, may be fertile or sterile. Acontia present." The above is the definition used by Haddon in "The Actiniaria of the Torres Straits" in 1898. There has been a great deal of discussion concerning this family.

Many other authors in defining the family include the provision of the "sphincter muscle mesogloeal." This is not important, as Bourne has shown the presence of an endodermal sphincter in Metridium (Actinoloba). Again, other authors define this family as " Hexactiniæ furnished with acontia." 
Sub-FAmily. SAGARTIN "Sagartidæ (Verrill).
with naked ectoderm. Cinclides usually present." (Haddon.)

Genus Sagartia (Gosse, 1855).

"Sagartinæ with smooth body-wall; margin tentaculate; sphincter fairly strong; tentacles concealed in contraction." (Haddon.)

\section{Sagartia miniata (Gosse).}

Gosse regarded S. miniata as the type species of his genus Sagartia. Gosse had made the possession of two œsophageal grooves one of the important characters of the genus, but now it has been proved that many of the typical Sagartids possess one as often as two grooves.

Specimens of $S$. miniata were kindly sent here by Miss Delap from Valentia Island. When they arrived they were still alive, but not in a condition fit for observation.

Column colour varying shades of orange, passing from pale below to either a dark chocolate, or purplish at the summit. Suckers irregularly arranged, but more numerous and conspicuous near the summit.

Tentacles of the outer cycle all possessed the crimson core and showed the following variations :-

(a) Light orange-crimson core.

(b) Lake, with orange-crimson core.

(c) Pale flesh-coloured, with light orange-crimson core.

Tentacles of inner cycle dusky, with indistinct white bar across inner face.

Tentacles of the Middle Series, crimson lake, resembling those of S. rosea.

Tentacles of the Marginal Series, usually pale reddish white, with three black patches on the inner face and a yellowish area about the base. This specimen had also a white transverse bar at the tentacle foot within the dark area on the periphery of the disk. Acontia white, very freely emitted.

The following are the measurements taken from a preserved specimen:-

Diameter of pedal disk . . . . $13 \mathrm{~mm}$.

, " column . . . . $7 \mathrm{~mm}$.

Height of column . . . . . $18 \mathrm{~mm}$.

Length of tentacles . . . . . . $3 \mathrm{~mm}$.

Comparing the size of this specimen with that of S. viduata described by Carlgren in "Studien über Nordische Actinien," 1893, I find that 
S. miniata is a much smaller anemone, $S$. viduata being about $50 \mathrm{~mm}$. long and $15 \mathrm{~mm}$. broad. S. viduata is also characterised by grey, green, and brown colours instead of the lake, orange, and crimson found in S. miniata. In $S$. viduata the warts (which Gosse called suckers) lie in the upper third of the column. The cinclides open in the middle of these prominences. In $S$. miniata, the cinclides seem to be very few, opening, as in S. viduata, in the middle of some of these prominences near the oral disk.

Arrangement of the mesenteries.

In S. viduata, Carlgren has found a definite number of mesenteries, i.e. 96 pairs, including two pairs of directives, arranged in five cycles thus, $-6+6+12+24+48$. The last cycle is represented by mere projections of tissue developed in the lowest part of the column. In this species the arrangement coincides with the number and arrangement of the tentacles which are in 6 cycles, $6+6+12+24+48+96=192$. I have cut sections of several specimens of $S$. miniata but am unable to make out any definite plan of the arrangement and number of mesenteries. The same difficulty has arisen in connection with other members of this genus, in S. venusta, S. troglodytes, and S. nivea.

In his paper "On the arrangement of the mesenteries in the Genus Sagartia," in Proc. R.D.S., 1888, F. Dixon says that he was unable in most cases to recognise a completely hexamerous arrangement of the mesenteries. The only regularity seen was the correspondence of the number of directives with that of the œsophageal grooves. Dixon gives the number of mesenteries, etc., from three specimens collected near Dalkey Island. The following data are taken from three specimens from Valentia Island, probably older and larger than those examined by Dixon :-

Specimen $(a)$ : 20 pairs of mesenteries reaching the œsophagus, including 1 pair of directives. There is 1 œesophageal groove present. About 20 pairs belong to 2 nd cycle and are incomplete. The 3rd cycle consists of about 40 small mesenteries which penetrate only a very short distance into the cœlenteron.

Specimen $(b)$ : This has 24 pairs of mesenteries reaching the œsophagus, including 2 pairs of directives arranged in the order :

$$
\text { D. 9, D. } 13 .
$$

The 2nd cycle consists of about 24 mesenteries, and the 3 rd cycle of about 48 ; these latter project only a short distance beyond the column wall. There are 2 œsophageal grooves here.

Specimen $(c)$ : This showed 1 œsophageal groove and 1 pair of direc- 
tives. The number of mesenteries reaching the œsophagus was about 24 pairs, including the directives.

The column wall is strong, the mesogloea being much thicker than the ectoderm. The ectoderm has a spongy appearance and contains a large number of gland cells, which are arranged near the outer margin, and most of them contain a granular substance like those of S. viduata. The opening of the cinclides is like that described and figured by Carlgren for S. viduata; the canal consists exclusively of ectoderm, endoderm only beginning at the inner end.

The mesogloea has a fibrous appearance when examined under a low power of the microscope, but under the high power, the cavities of the cells give it an almost spongy appearance. The cells become smaller and the whole mesogloea becomes stronger near the endodermal margin, and this gives rise to an endodermal muscle. As in $S$. viduata this is fairly well developed and much folded in transverse section. The folds are not branched and are irregular in shape. In the upper part of the column the muscle is differentiated into a mesogloeal sphincter which is very strong especially at the top, diminishing downwards. There are numerous mesogloeal processes projecting into the endoderm, and they are deeply set and are often branched. These projections are not present in the sphincter muscle of S. viduata as figured in "Nordische Actinien." The endoderm of the column wall is of about the same thickness as the ectoderm and contains numerous zooxanthellæ; and the number of these increases on the mesenteries, especially in the region near the œsophagus.

The primary mesenteries all have a large and well-developed retractor muscle.

As in $S$. viduata and $S$. undata, the muscle cushions of the directive septa are quite near the œsophagus, while those of the remaining septa are nearer the middle of the septa. The former are more concentrated and higher than the latter, which are extensive and more shallow. The retractor muscle is of the usual shape and contains a large number of arborescent folds.

In the largest specimen $(c)$ this muscle in section was divided up into a number of folds, each fold being supplied with numerous mesogloeal fibres, as shown in the figure (Fig. 1). In this way the whole septum is very much elongated.

The parieto-basilar muscle is well developed and appears very long in cross section, and most of the mesogloeal processes arise from the side on which the retractor muscle occurs. These processes are not numerous 


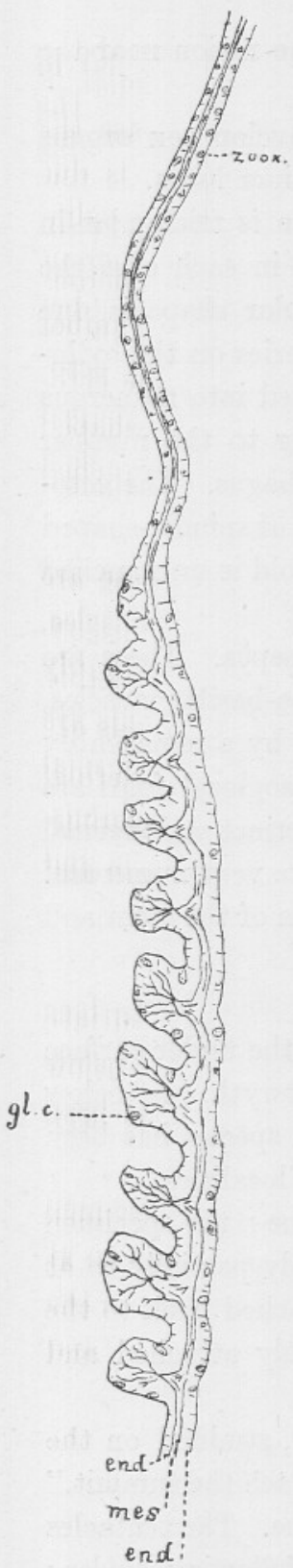

*Frg. 1. - Sagartia miniata. Transverse section of a portion of a mesentery from a large specimen, showing the curious folding of the retractor muscle.

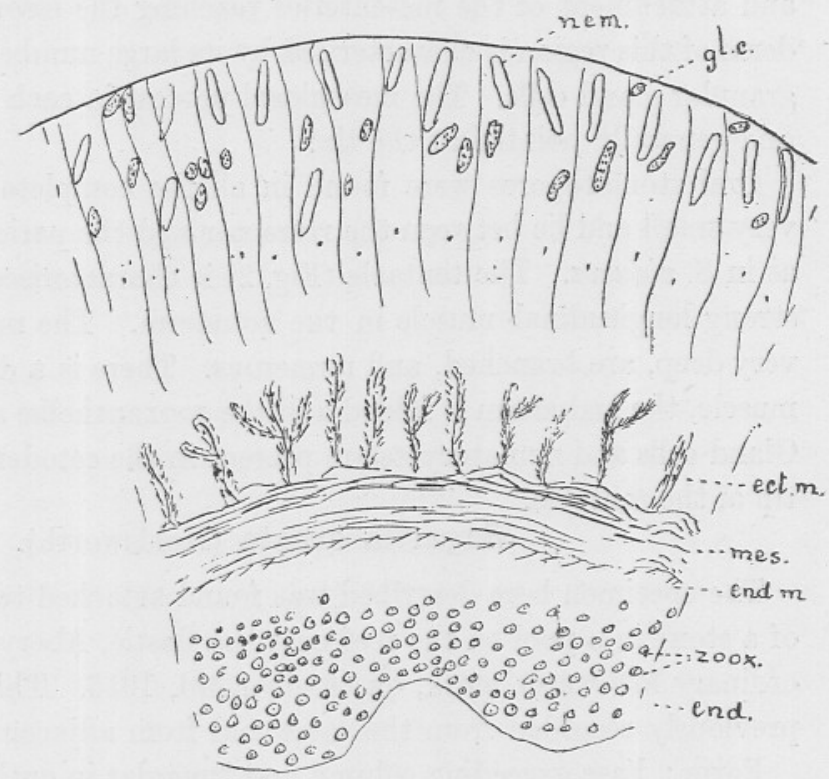

FIg, 2,-Sagartia miniata. Portion of the tentacle wall, showing the strongly dereloped ectodermal muscle.

* For Index to Lettering, see page 552. 
and are very small near the base, but get large in the region near the retractor muscle.

Many of the mesenteries which are incomplete develop sex organs and mesenterial filaments. The latter have three distinct lobes.

The stomatodæum is very long and in cross section is triangular in shape in all the specimens that I examined, because in each case the specimen was more or less contracted. This triangular shape is due probably to the equal pressure exerted by the mesenteries on the cylindrical œsophagus during contraction. The wall is raised into numerous folds, the number and position usually corresponding to the number and attachment of the mesenteries reaching the œsophagus. The ectoderm of this region is characterised by its large number of spindle-shaped granular gland cells. The mesogloeal process in each fold is unbranched and generally pointed at the tip.

Oral stomatopores were found in all the complete septa. These are very small and lie between the retractor and the parieto-basilar muscles, as in S. viduata. The tentacle (Fig. 2) is characterised by a remarkably strong longitudinal muscle in the ectoderm. The mesogloeal folds are very deep, are branched, and numerous. There is a distinct endodermal muscle, the endoderm is folded and the zooxanthellæ are very numerous. Gland cells and nematocysts are present in the ectoderm of the stem and tip of the tentacle.

\section{Sagartia ornata (Holdsworth).}

The specimen here described was found attached to the under surface of a stone in a pool on the reef near the Castle, Aberystwyth, just below ordinary low-water mark, on October 3rd, 1913. This species has been previously recorded from the same and from adjacent localities.

Form : base exceeding column and irregular in outline; the specimen was never seen fully expanded in the day time and only partially so at night. Soon after its capture it left the stone and attached itself to the vessel in which it was kept, and there remained firmly attached and much flattened.

Column, according to Gosse, " minutely corrugated, studded on the upper half with 'suckers,' more numerous as they approach the summit." A fair amount of mucus was given off from time to time. The tentacles appear to be about 96, probably arranged in the following cycles: $6+6+12+24+48$. They are rather short and obtuse at the tip.

Disk (seen only by artificial light), mouth appeared slightly raised, lips somewhat thickened. Esophageal grooves could be distinguished. Acontia, one was seen emitted from the mouth. 
Colour : column buff, paler at base, with numerous faint longitudinal lines best marked near the base.

Disk pale yellow in the centre, darker on the outer area, radii paler. A cycle of twelve distinct, nearly circular white spots is situated at the junction of the two-colour areas.

Tentacles dark chocolate-brown or mahogany, paler towards the tips ; the tentacles of outer cycles are paler than those of the inner, and have the basal bar more prominent. Innermost tentacles more or less dusky, but always darker on their inner faces. There are three or four white bars on this side; Holdsworth calls them "rings," but if so they are very indistinct on their outer faces. The apical bar is often very faint or barely visible; the basal bar, the third or fourth from the tip, is very distinct.

The following measurements were taken from a preserved specimen :-

Diameter of pedal disk $=7 \mathrm{~mm}$.

$\begin{array}{ll}\text { Height of column } & =4 \mathrm{~mm} . \\ \text { Length of tentacles } & =2 \mathrm{~mm} \text {. }\end{array}$

Arrangement of the mesenteries: This specimen shows an hexamerous arrangement. There are four cycles, $6+6+12+24=48$. The mesenteries of the first two cycles are fully formed bearing reproductive organs and mesenterial filaments. There are two pairs of directives and two œsophageal grooves. The 4 th cycle of mesenteries is only slightly developed.

The column wall is not very strong, the mesogloea being less than half the thickness of the ectoderm. The latter is a broad layer consisting of tall columnar cells, which seem to get broader near the outer edge. This ectoderm has an appearance quite different from that of $S$. miniata, where it is more spongy and the cells are neither so regularly arranged nor of such a uniform size as those of S. ornata. Gland cells seem to be absent in the ectoderm of the column wall.

The mesogloea is not very dense and a fibrous structure is distinctly visible; the fibres are very fine and form a close network, which becomes denser near the endoderm. The mesogloea is not of uniform thickness, because the ectoderm is raised into folds and these are supported by processes of mesogloea, at any rate in a state of contraction. In transverse sections near the summit of the column I have found a few cinclides, but I have not found them present between two septa of a pair, as Carlgren found in S. undata. The structure of these openings is the same as that described for $S$. viduata and $S$. miniata; they are ectodermal invaginations. 
In the mesenteries (Fig. 4) of the first two cycles the parieto-basilar is comparatively strong; it is slightly constricted near the base, and is an elongated muscle. Most of the muscle folds are given off on one side only. These folds are short and stout, sometimes globular at the head, sometimes slightly branched. Before the parieto-basilar muscle passes into the retractor muscle the former becomes swollen and a projection of the mesogloea sends out a number of branches towards the edge away from the retractor muscle.

The longitudinal retractor muscle is rectangular in section and has an appearance quite different from that of $S$. miniata. In the latter the muscle folds are delicate and very numerous-about 80 in number; while in $S$. ornata the folds are fairly short and stout and number only about $10-20$.

Oral stomatopores are present in the complete mesenteries, and there are slits between the retractor and parieto-basilar muscles.

The mesenteries of the third cycle reach about half-way across the cœlenteron. Each mesentery has a stout axis of mesogloea, which gives off about five branches.

The mesenteries of the 4th cycle are present in the lower half of the column only. They are very small and are indicated by a thin projection of mesogloea surrounded by a layer of endoderm.

Stomatodaeum. The two œsophageal grooves are well marked. The ectoderm is thick and has a granular zone near the free surface. The mesogloea is thick near the base of the groove, but becomes thinner along the sides of the groove. The wall of the stomatodaeum is raised into about 24 deep folds, corresponding to the number and attachment of the mesenteries, and the ectoderm of these folds contain a large number of gland cells whose contents are not granular.

The sphincter muscle (Fig. 5) is a mesogloeal one. It is very much like that of S. milmani (H. and S.) figured by Haddon in Trans. R.D.S., 1898. The cavities in the muscle are large and numerous and tend to radiate in the same direction as shown in the figure. The broadest region is near the summit, while lower down in the column wall the muscle becomes very narrow and the cavities become fewer. The gland cells of the ectoderm in this region contain a number of spherical bodies which are highly refractive.

Tentacles. Near the tip the ectoderm is more than twice as thick as the rest of the tissue. In a section through this region of a tentacle there are very numerous nematocysts, some seen in section and some seen from the side. They are fairly short and stout, spindle-shaped bodies, 
and a fine, much-coiled spiral thread is faintly distinguished in one or two cases. Near the base of the tentacle (Fig. 3) the endoderm is
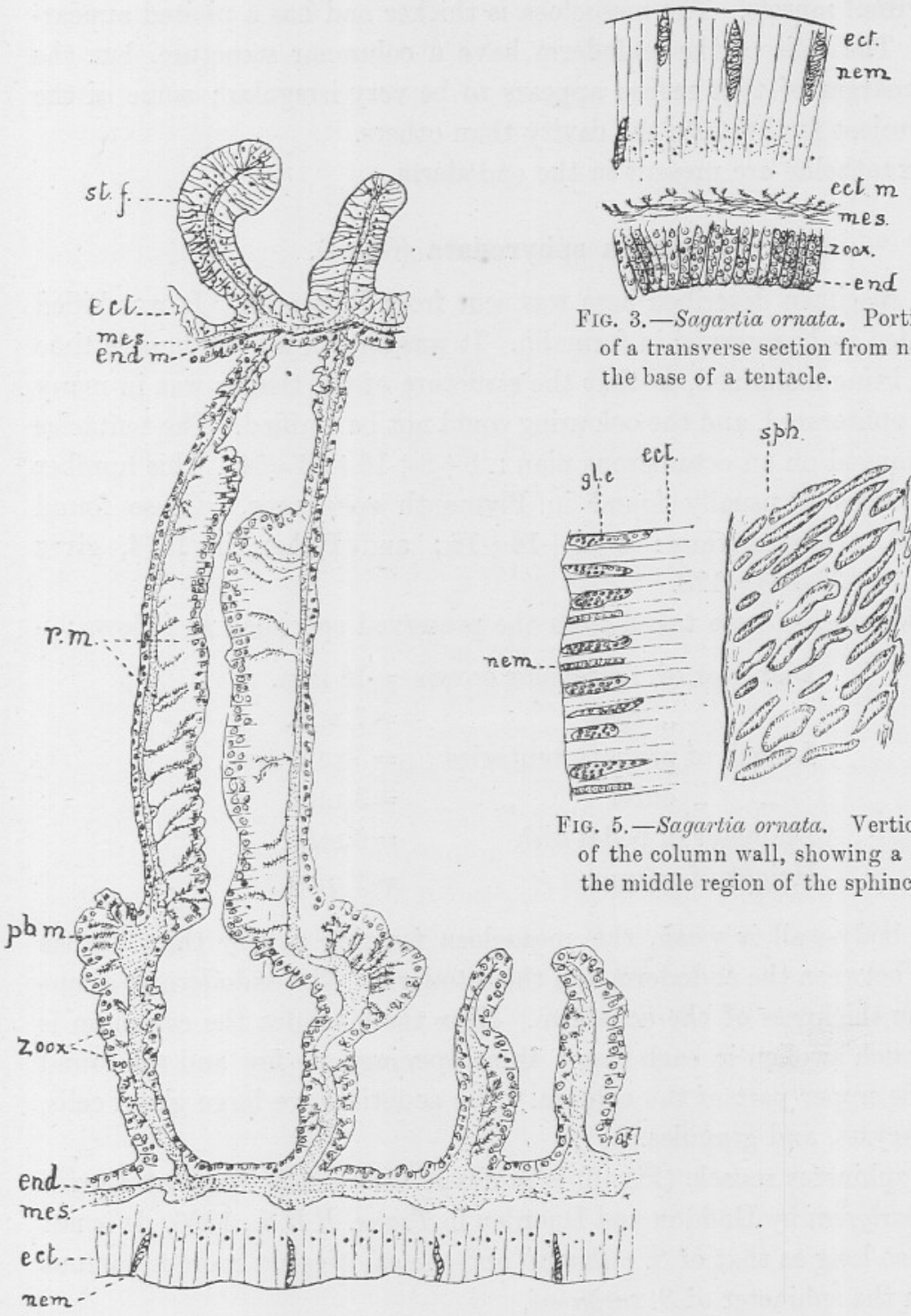

FIG. 3.-Sagartia ornata. Portion of a transverse section from near the base of a tentacle.

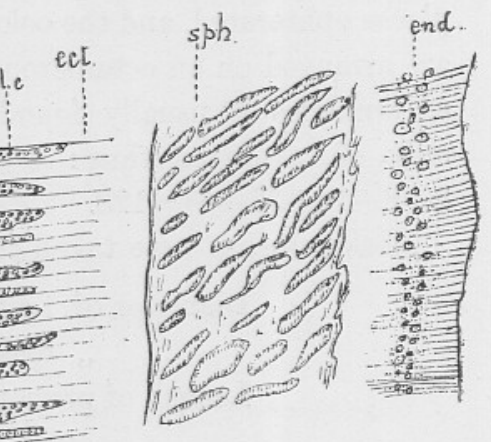

IG. 5.-Sagartia ornata. Vertical section of the column wall, showing a portion of the middle region of the sphincter.

Fig. 4.- Sagartia ornata. Portion of a transverse section through the column, showing two complete mesenteries and two mesenteries of the third series.

narrower and the nematocysts, although very numerous, are fewer in number than above. The mesogloea is not strong and in some cases is reduced to a fine strand. 
At the point where the tentacle joins on to the peristome the tissues are much thicker, the nerve layer is much broader, and there is a stronger ectodermal muscle. The mesogloea is thicker and has a plaited appearance. The cells of the endoderm have a columnar structure, but the inner margin of that region appears to be very irregular; some of the cells project farther into the cavity than others.

Zooxanthellæ are present in the endoderm.

\section{Sagartia sphyrodeta (Gosse).}

The specimen described here was sent from Plymouth. It was killed expanded and preserved in formalin. It was left for a considerable time before being examined, so that the structure of the tissues was in many places obliterated, and the colouring could not be verified. The tentacles are arranged on an octamerous plan : $8+8+16+32=64$. This number of tentacles is usually found in Plymouth specimens. Gosse found only 48, arranged thus: $8+8+16+16$; and Fisher, in 1874, gives $8+8+16+32+64=128$.

Measurements were taken from the preserved specimen as follows :-

$\begin{aligned} \text { Diameter of tentacular crown } & =18 \mathrm{~mm} . \\ \text { Length of primary tentacles } & =5 \text { to } 6 \mathrm{~mm} . \\ \text { ", , outer " } & =3 \mathrm{~mm} . \\ \text { Diameter of pedal disk } & =6 \mathrm{~mm} . \\ \text { Height of column } & =4 \mathrm{~mm} .\end{aligned}$

The body-wall is weak, the mesogloea forming a very thin, fibrous strand between the endoderm and the ectoderm. The endoderm is about half the thickness of the ectoderm. Near the cinclides the ectoderm is very much swollen in each case ; these openings are few and are found near the upper part of the column. The acontia have large gland cells, nematocysts, and granules.

The sphincter muscle (Fig. 6) is in shape very much like that figured for S. carlgreni by Haddon and Duerden in Trans. R.D.S., 1896. It is not nearly so long as that of $S$. milmani, and the cavities are more numerous than in the sphincter of $S$. carlgreni.

The mesenteries (Fig. 7) are very weak, the retractor muscle forms a shallow cushion, and the parieto-basilar muscle is very long and thin. The endoderm contains numerous oval gland cells, which are full of deeply stained granules.

The œsophagus has one groove ; the folds in the ectoderm of the wall 
are neither so deep nor so regularly arranged as those examined in S. miniata and S. ornata.

In the upper part of the column wall a very strong radial ectodermal muscle is present; an endodermal muscle is also present. There are

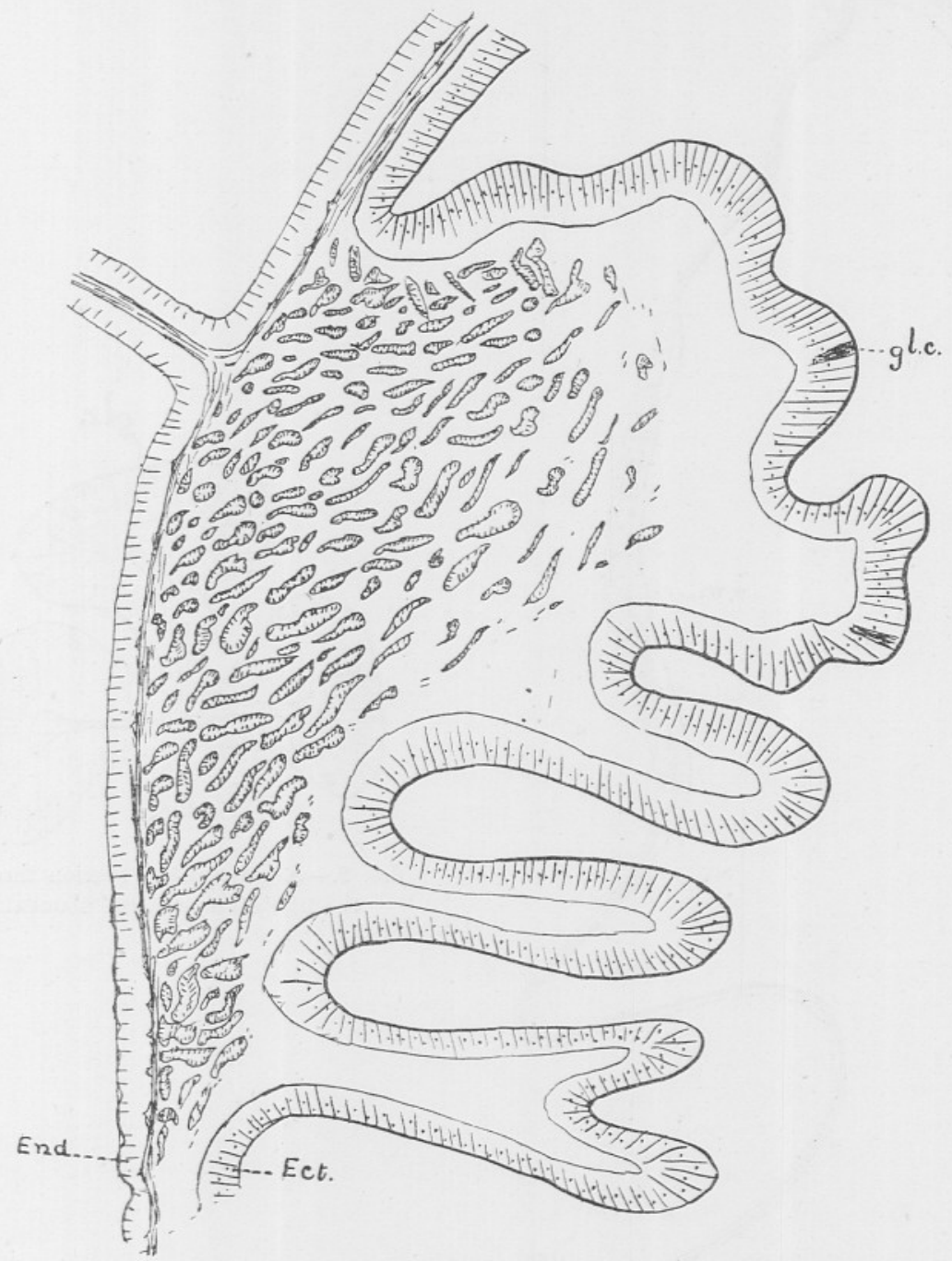

FIG. 6.-S. sphyrodeta. Vertical section through the body-wall, showing the sphincter muscle.

three distinct lobes to the mesenterial filaments (Fig. 8); they are shaped differently from those figured for S. milmani.

The mesogloea in the tentacle is very weak and the endoderm forms a very thin layer. 


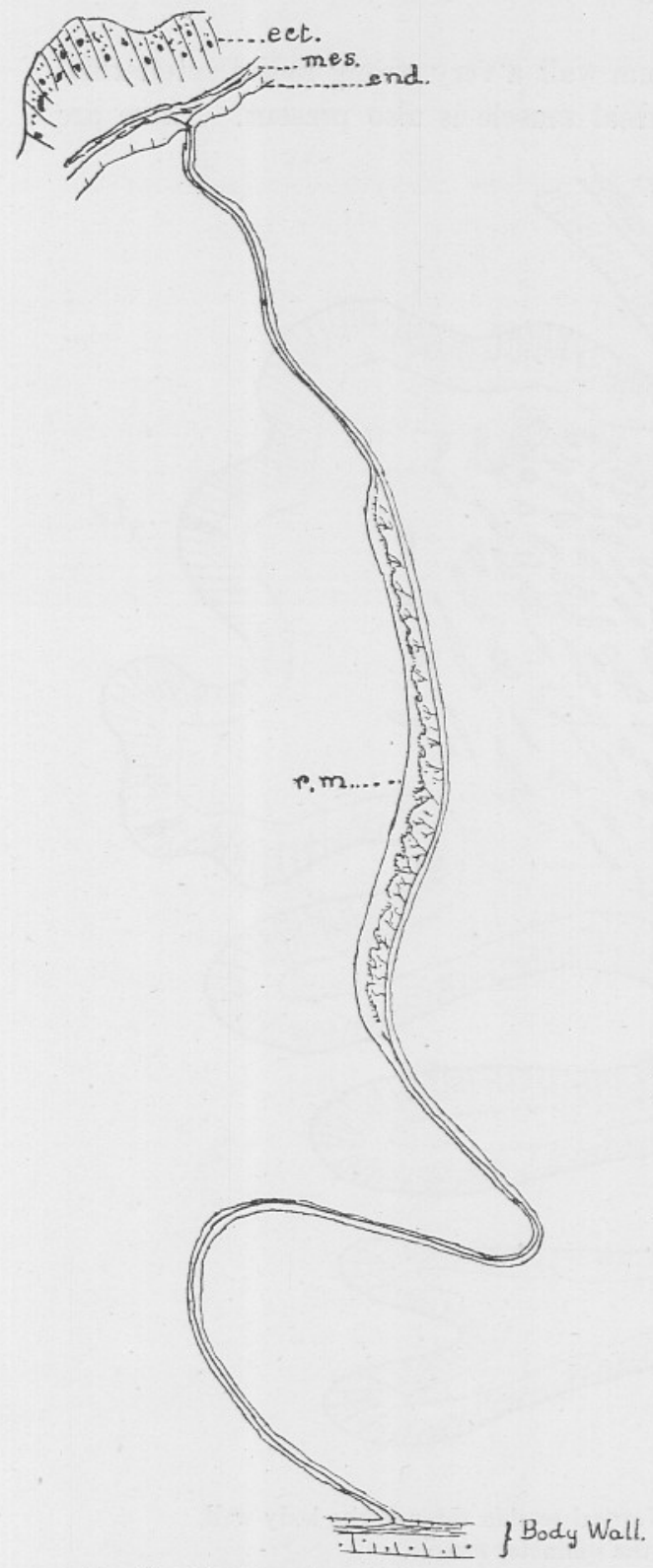

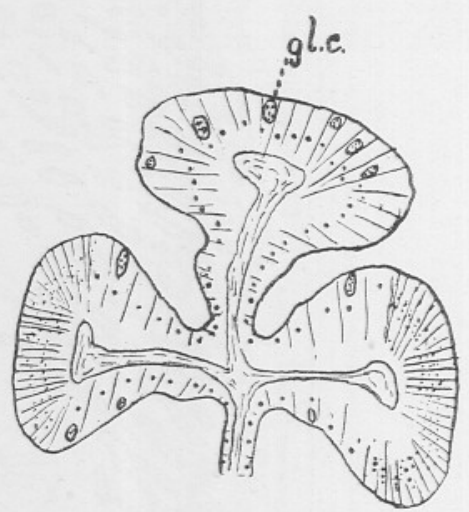

FIG. 8.-S. sphyrodeta. Section through the trilobed mesenterial filament.

FIG. 7.-S. sphyrodeta. Transverse section through a young specimen in a fully expanded condition, showing one of the perfect mesenteries. 
S. sphyrodeta resembles S. milmani (H. and S.) in the following respects :-

1. The mesogloea is not thick.

2. The mesenterial filaments are weak.

3. The parieto-basilar muscle is very feeble; only a few small folds can be seen on the side of the mesentery bearing the retractor muscle.

With regard to character and shape, the sphincter of S. sphyrodeta resembles the sphincter of $S$. carlgreni, but the arrangement of the mesenteries is quite different in the three species.

S. milmani has 48 mesenteries, among which a sex radiate symmetry is maintained thus: $12+12+24$. There are two pairs of directives arranged thus :-

$$
\text { D. } 4, \text { D. } 6 \text {. }
$$

In $S$. carlgreni the mesenterial formula is $6+6+12+24=48$.

In $S$. sphyrodeta there is one œsophageal groove and one pair of directives.

The mesenteries are irregularly arranged and I am unable to make a mesenterial formula. Since the tentacles are arranged on an octamerous plan we should expect the mesenteries to be arranged in the same way. In a young specimen I counted 20 pairs and one odd mesentery. Some of these were complete and bore reproductive organs, the others were rudimentary. In an older specimen there were 48 pairs of mesenteries arranged, probably, in four cycles.

The mesenteries of this species are stronger and the retractor muscle forms a definite cushion with branched muscle folds. 
COMPARATIVE TABLE OF BRITISH SPECIES OF SAGARTIA YOR WHICH ANATOMICAL DATA ARE OBTAINABLE.

\begin{tabular}{|c|c|c|c|c|}
\hline \multirow{2}{*}{ Anatomical Features. } & \multicolumn{4}{|c|}{$\begin{array}{l}\text { Data given by O. Carlgren, Stud. über Nord. Act. Kongl. Sv. Vet. Akad., } \\
\text { Bd. } 25, \text { No. } 10 .\end{array}$} \\
\hline & S. viduata. & S. undata $\alpha$. & S. undata $\beta$. & S. undata-troglodytes. \\
\hline \multirow{2}{*}{ Column Colour. } & $\begin{array}{l}\text { (Norway.) Ground } \\
\text { colourgrey-green, } \\
\text { yellow-brown or } \\
\text { green lines. }\end{array}$ & $\begin{array}{c}\text { (Norway.) Red- } \\
\text { brown or dull } \\
\text { brown,small flesh- } \\
\text { coloured stripes. }\end{array}$ & $\begin{array}{l}\text { (Norway.) Red } \\
\text { spots on white } \\
\text { or flesh-coloured } \\
\text { ground. }\end{array}$ & $\begin{array}{l}\text { (Norway.) Salmon } \\
\text { or flesh colour, } \\
\text { sometimes grey- } \\
\text { green. }\end{array}$ \\
\hline & $\begin{array}{l}\text { (Great Britain.) } \\
\text { Ground colour } \\
\text { pinkish buff, } \\
\text { white or yellow- } \\
\text { ish lines. } \\
\end{array}$ & \multicolumn{3}{|c|}{$\begin{array}{l}\text { (Great Britain.) } \\
\text { Olive-green, brown, grey, pink, numerous longitudinal } \\
\text { stripes. Gosse recognised about } 20 \text { varieties. }\end{array}$} \\
\hline Disk Colour. & $\begin{array}{l}\text { Ochreous grey } \\
\text { radial lines, green } \\
\text { or yellowish } \\
\text { spots. }\end{array}$ & $\begin{array}{l}\text { Ochre-orange radial } \\
\text { lines. } \\
\text { B. mark at tentacle } \\
\text { basis. }\end{array}$ & $\begin{array}{l}\text { Brownish or orange } \\
\text { with white lines. } \\
\text { Red or red-brown } \\
\text { B. marks at ten- } \\
\text { tacle bases. }\end{array}$ & $\begin{array}{l}\text { White to ochre lines } \\
\text { on grey or grey- } \\
\text { black ground. } \\
\text { Black B. marks at } \\
\text { tentacle bases. }\end{array}$ \\
\hline \multirow{2}{*}{ Tentacles. } & $\begin{array}{l}\text { Fine, tapering, } \\
\text { often branched. }\end{array}$ & Tentacles & long and & tapering. \\
\hline & $\begin{array}{l}6+6+12+24+ \\
\quad 48+96=192\end{array}$ & $\begin{array}{l}6+7+13+26+52 \\
\quad=104\end{array}$ & In 6's or 5's or 8's. & In 6's. \\
\hline \multirow{2}{*}{ Mesenteries. } & $\begin{array}{l}6+6+12+24+48 \\
\quad=96\end{array}$ & In 5's or 7's. & Usually in 8's. & $6+6+12+24=48$ \\
\hline & $\begin{array}{l}\text { Two pairs of direc- } \\
\text { tives. }\end{array}$ & & . & \\
\hline Esophageal Grooves. & Two grooves. & \multicolumn{3}{|c|}{ Two grooves or one groove-sometimes three grooves. } \\
\hline \multirow{2}{*}{ 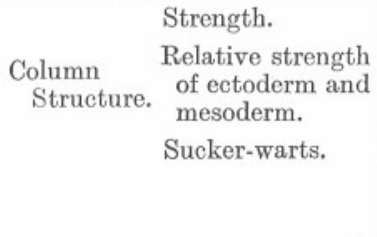 } & $\begin{array}{l}\text { Strong. } \\
\text { E. and M. of same } \\
\text { thickness. }\end{array}$ & $\begin{array}{l}\text { Firm. } \\
\text { E. and M. of same } \\
\quad \text { thickness. }\end{array}$ & $\begin{array}{l}\text { Firm. } \\
\text { E. and M. of same } \\
\text { thickness. }\end{array}$ & $\begin{array}{l}\text { Firm. } \\
\text { E. and M. of same } \\
\text { thickness. }\end{array}$ \\
\hline & $\begin{array}{l}\text { Small, cinclides } \\
\text { open on some. }\end{array}$ & - Never & distinct. & $\begin{array}{l}\text { Common on upper } \\
\text { part, cinclides } \\
\text { open on some. }\end{array}$ \\
\hline \multirow[t]{2}{*}{ Sphincter. } & $\begin{array}{l}\text { Mesogloeal, strong } \\
\text { at the top. }\end{array}$ & \multicolumn{3}{|c|}{$\begin{array}{l}\text { Mesogloeal muscle masses radial and more rounded than } \\
\text { in S. viduata. }\end{array}$} \\
\hline & & & $\begin{array}{l}\text { This is possibly iden- } \\
\text { tical with Gosse's } \\
\text { (not Miiller's) Sag- } \\
\text { artiacocinea accord- } \\
\text { ing to Carlgren. }\end{array}$ & \\
\hline
\end{tabular}

\begin{tabular}{|c|c|c|c|c|}
\hline \multirow{3}{*}{$\begin{array}{l}\text { S. miniata } \\
\text { (from } 3 \text { British } \\
\text { specimens). } \\
\begin{array}{l}\text { Orange. Pale below, } \\
\text { dark chocolate } \\
\text { above. }\end{array}\end{array}$} & \multirow{3}{*}{\begin{tabular}{|c|} 
S. ornata \\
(from 2 British \\
specimens). \\
$\begin{array}{c}\text { Buff, pale at base, } \\
\text { with numerous } \\
\text { longitudinal lines. }\end{array}$
\end{tabular}} & \multirow{2}{*}{\multicolumn{2}{|c|}{$\begin{array}{l}\text { Anatomical Data given by Messrs. } \\
\text { Dixon, Proc. R. Dubl. Soc., } 1888-9 \text {, etc. } \\
\begin{array}{ll}\text { S. nivea. } & \text { S. venusta. }\end{array}\end{array}$}} & \multirow{2}{*}{$\begin{array}{l}\text { S. sphyrodeta } \\
\text { (from } 3 \text { British speci- } \\
\text { mens). }\end{array}$} \\
\hline & & & & \\
\hline & & $\begin{array}{l}\text { Pale brown with } \\
\text { white lines. }\end{array}$ & $\begin{array}{l}\text { Upper half buff to } \\
\text { brown, lower half } \\
\text { paler with faint } \\
\text { white stripes. }\end{array}$ & $\begin{array}{l}\text { White with dull } \\
\text { drab stripes, } \\
\text { some varieties } \\
\text { yellow. }\end{array}$ \\
\hline $\begin{array}{l}\text { Centre olive to } \\
\text { orange whitish } \\
\text { radial lines. }\end{array}$ & $\begin{array}{l}\text { Umber to purple- } \\
\text { brown. Yellow } \\
\text { radial lines with } \\
\text { white spots be- } \\
\text { tween. }\end{array}$ & White to olive. & $\begin{array}{l}\text { Varying shades of } \\
\text { orange. }\end{array}$ & $\begin{array}{l}\text { White, sometimes } \\
\text { yellow, with } \\
\text { radial lines. }\end{array}$ \\
\hline Tapering. & $\begin{array}{l}\text { Short, with obtuse } \\
\text { tips. }\end{array}$ & $\begin{array}{l}\text { Tapering. Outer } \\
\text { cycles may be } \\
\text { reduced to pa- } \\
\text { pillæ. }\end{array}$ & $\begin{array}{l}\text { Tapering. Outer } \\
\text { cycles may be } \\
\text { reduced to pa- } \\
\text { pillæ. }\end{array}$ & $\begin{array}{l}\text { Short and stout, } \\
\text { thickened to- } \\
\text { wards the base. }\end{array}$ \\
\hline $\begin{array}{l}\text { Difficult to esti- } \\
\text { mate. Probably } \\
\text { in } 6 \text { 's. }\end{array}$ & $\begin{array}{l}6+6+12+24+48 \\
\quad=96\end{array}$ & $\begin{array}{l}6+6+12+24+48 \\
\quad+96=192\end{array}$ & $\begin{array}{l}6+6+12+24+48 \\
\quad+96=192\end{array}$ & $8+8+16+32=64$ \\
\hline $\begin{array}{c}\text { Either } 20+20+40 \\
=80 \text {, or } 6+6+12 \\
+24+48=96 . \\
\text { One or two pairs } \\
\text { of directives. }\end{array}$ & $\begin{array}{l}\begin{array}{l}6+6+12+24+48 \\
\quad=96 .\end{array} \\
2 \text { pairs of directives. }\end{array}$ & $\begin{array}{l}6+6+12+24=48 \\
1 \text { pair of directives. }\end{array}$ & $\begin{array}{l}6+6+12+24+48 \\
\quad=96 \\
1 \text { pair of directives. }\end{array}$ & $\begin{array}{l}\text { Either } 5+5+10=20 \text {, } \\
\quad \text { or } 6+6+12+24 \\
=48 . \\
1 \text { pair of directives. }\end{array}$ \\
\hline One or two grooves. & Two grooves. & One groove. & One groove. & One groove. \\
\hline $\begin{array}{l}\text { Strong. } \\
\text { E. thinner than } \\
\text { mesoderm. }\end{array}$ & $\begin{array}{l}\text { Weak. } \\
\text { E. twice as thick as } \\
\text { mesoderm. }\end{array}$ & $\begin{array}{l}\text { Moderate. } \\
\text { M. thicker than E. }\end{array}$ & $\begin{array}{l}\text { Strong. } \\
\text { M. irreg. thicker } \\
\text { than E. in many } \\
\text { places. }\end{array}$ & $\begin{array}{l}\text { Weak. } \\
\text { Mesoderm thin. }\end{array}$ \\
\hline $\begin{array}{l}\text { Around summit of } \\
\text { column, oval. } \\
\text { A few cinclides, } \\
\text { open on some of } \\
\text { the warts. }\end{array}$ & $\begin{array}{l}\text { Numerous on the } \\
\text { upper half. A few } \\
\text { cinclides, open } \\
\text { on some of the } \\
\text { warts. }\end{array}$ & $\begin{array}{l}\text { On upper half, some } \\
\text { on upper third } \\
\text { perforated by } \\
\text { cinclides. }\end{array}$ & $\begin{array}{l}\text { On upper half, } \\
\text { some on upper } \\
\text { third are perfor- } \\
\text { ated by cinclides. }\end{array}$ & $\begin{array}{l}\text { Few, found on } \\
\text { upper part of } \\
\text { column, perfor- } \\
\text { ated by cinclides. }\end{array}$ \\
\hline $\begin{array}{l}\text { Mesogloeal, strong } \\
\text { at the top, dimin- } \\
\text { ishing down- } \\
\text { wards, projec- } \\
\text { tions into the } \\
\text { endoderm. }\end{array}$ & $\begin{array}{l}\text { Mesogloeal, not so } \\
\text { broad at top as } \\
\text { in S. sphyrodeta. }\end{array}$ & . & & $\begin{array}{l}\text { Mesogloeal, fairly } \\
\text { broad at top. }\end{array}$ \\
\hline
\end{tabular}




\section{Anthopleura alfordi (Gosse).}

Classification.-Family Cribrinidæ, McMurrich (=Bunodidæ, Gosse). Genus, Anthopleura, Duchassaing et Michelotti (=Aulactinia, Verrill).

The following definition of the genus is that given by McMurrich under the name of Aulactinia: "Bunodidæ with the upper portion of the column provided with longitudinal rows of verrucæ, the lower portion being smooth. The margin forms a more or less distinct collar, and the tentacles are polycyclic and entacmæous. The six pairs of mesenteries of the first cycle are alone perfect."

Haddon has queried the last statement of the above [11, page 442] because he includes in Aulactinia a species Aulactinia gelam (=Condylactis gelam, Hadd. and Shackl., 1893) from the Torres Straits which has more than six pairs of mesenteries.

The specimen of Anthopleura alfordi which I have examined also has more than six pairs of perfect mesenteries. Therefore if these two species, Anthopleura gelam and Anthopleura alfordi, are to be included in the genus Aulactinia, the definition of the genus will have to be slightly altered (see end of this section).

Externally, the genus Aulactinia differs from the genus Cribrina (Bunodes) in having suckers in the upper portion of the body-wall only ; whereas the latter genus is more or less uniformly tuberculated. Delage and Hérouard in describing the genus Aulactinia say that there are four or five cycles of mesenteries, but in this specimen of $A$. alfordi I have found only two cycles, one of complete mesenteries and another of incomplete mesenteries ; there is no indication of a third cycle.

The external characters of this species have been described by Gosse (Ann. Mag. Nat. Hist., 3rd Series, Vol. XVI, 1865), under the name Egeon alfordi of the family Antheadæ.

The specimen which I have examined was kindly sent from Valentia Island by Miss M. Delap, in May, 1914.

External characters: (The animal was living, but moribund after the long journey.) The following description applies to the above specimen :-

Pedal disk: outline slightly irregular, in size scarcely exceeding column ; wrinkled and appears capable of but slight adhesion.

Column somewhat changeable in form; at times widest about the middle, at others considerably expanded at the summit. Substance somewhat lax. The margin is crenulated with a series of larger irregular 
warts-the acrorhagi. The warts get smaller in the region near the base, as shown in the figure included by Gosse in his paper. Many of the vertical rows of warts die out rapidly downward, while even the primary rows become faint and the warts distant; the whole of the intervening space is wrinkled (probably owing to the animal being partially contracted).

Tentacular disk : diameter exceeding that of column; mouth rather large, lips somewhat pouting, gonidial tubercles or acrorhagi prominent and inflated.

Tentacles stout, lax, of no great length, tapering but slightly to an obtuse tip, conical during contraction. When the animal is not fully expanded there is a distinct fosse between the margin of the warted column and the base of the tentacles. Tentacles contractile, but not retractile, bear a considerable resemblance to those of Aiptasia. Owing to the laxity of the tentacles it was extremely difficult to make a correct enumeration, or even to determine the number of series. There appear to be about a hundred tentacles, probably in the order $6+6+12+24+48$ $=96$. Fragments of sand adhered to the column wall, this suggests the presence of either numerous small suckers or adhesive mucus.

Colour : pedal disk pale yellowish white with a few small red streaks.

Column pale yellowish green, but so thickly covered with minute irregularly shaped red specks as to appear brick-red to the naked eye; only a few specks can be distinguished without a lens. There are also longitudinal series of larger spots of clear yellow-green, each with a bright red central dot; these spots are irregularly shaped and are well spaced in the series, nearer together and more prominent near the summit, where they are seen on the warts. The acrorhagi are of a leaden grey hue with several dull red spots on each. There are fifteen or sixteen of these red-centred spots in each linear series, and the spots are connected by faint lines of yellow-green. There is also a number of intermediate series of these red-centred dots on the upper part of the column, but these soon die out lower down. Thus the column possesses 24 longitudinal pale greenish yellow stripes, each of which contains 15 to 16 spots of a brighter yellow colour, with a bright red central dot.

Tentacular disk : stomatodaeum white, lip pale grey. Disk iridescent, umber or bluish green (according to the incidence of light) succeeded by an indefinite area of dull greyish white. The tentacle bases are of a much darker umber, the gonidial radii are fairly well demarcated and the mesenteries appear as faintly marked radial lines.

Tentacles umber, the inner faces shaded with iridescent purple. NEW sERIEs, - vol, $x$. No, 4. MAY, 1915. 
There are numbers of irregularly shaped spots of a pale yellow colour scattered over the inner surface of the tentacles. Each tentacle from the inner series has two opposite, lateral, irregular patches of white, situated about one-third the length of a tentacle from the base. The purple shade is strongest upon the central area of the inner surface of the tentacle.

The series of minute spots is described by Gosse and their presence seems to be characteristic of this species. Haddon does not mention their presence in A. gelam.

Size : diameter of column very variable during life, $6-10 \mathrm{~cm}$. Column $15 \mathrm{~cm}$. in height, but probably capable of much greater extension. Diameter of disk about $10 \mathrm{~cm}$. Expanse of tentacular crown about $20 \mathrm{~cm}$. Length of larger tentacles $7 \mathrm{~cm}$. Average diameter of pedal disk $7 \mathrm{~cm}$.

This specimen is about the same size as A. gelam; the height of the column of the latter being $150 \mathrm{~mm}$. The specimen of $A$. alfordi collected by Gosse was also fairly large, the height being about $100 \mathrm{~mm}$., it was obtained in the Scilly Isles.

The specimen from Valentia Island disgorged a partially digested Actinian-probably a Cerianthus ; a number of these were packed with the Aulactinia and were in contact with it.

Anatomy and Histology :-

The column wall is thick, the mesogloea being broader in section than the ectoderm ; the latter is deeply folded. The cells of the ectoderm are long and narrow ; they contain numerous granules, which become deeply stained. These granules form a broad zone in the ectoderm. On the outside of the layer is a clear zone, and on the inside near the mesogloea is another narrower zone, which marks the position of the nerve layer. Between these two lie the granules.

The mesogloea is thick, stains deeply and is homogeneous in structure. The large spaces which are seen in the sections are probably due to the fact that the specimen became very hard before the sections were cut, and this caused the mesogloea to break.

On its endodermal border the mesogloea shows a delicate fibrous structure, giving rise to a thin plate of circular endodermal muscle. There is no trace of any ectodermal musculature.

The endoderm is a much narrower layer; in section it is about half the width of the ectoderm and one-third the width of the mesogloea. The cells of the endoderm do not show such a definite columnar structure as those of the ectoderm, and the cells are not so regularly arranged. 
The spherical granules seen here are of the same kind as are found in the ectoderm. They are more numerous near the free border of the endoderm. Zooxanthellæ are present in the endoderm of the column wall, but are not very plentiful.

There are 24 pairs of fully developed mesenteries, 2 pairs being directives. Alternating with these are the secondary mesenteries, so that in all there are 24 primary pairs and 24 secondary pairs, making 48 .

The number of tentacles is the same as that of the mesenteries. All the primary mesenteries except the directives are fertile, and in this specimen bear gonads. The musculature in the mesenteries is strongly developed, especially in the region near the column wall (Fig. 10). The parieto-basilar muscle is cordate in shape with a stout projection on the side towards the intramesenterial space. The mesogloea forms a short stout stem where the muscle is attached to the column wall. The muscle then broadens out rapidly, giving off short processes on either side, and these are sometimes slightly branched. Most of them are narrow at the base, and widen out into broad spherical knobs at the distal ends. There are between 9 and 15 of these branches on either side. One side of this muscle is continued into the large retractor muscle; this is very wide in the region near the column wall, but becomes narrower towards the distal end of the mesentery, where it is continued into a very narrow plate of tissue. The mesogloea continuing from the parietobasilar muscle becomes slightly narrower before it enters the retractor muscle and is very thin where it enters the filament. On one side, the mesogloea has short stout projections, these send out long and delicate strands which are much branched. These strands are so numerous that they are not easy to count; the folds, including their chief branches, number between 80 and 100 .

At the distal end of the muscle the folds radiate towards the middle line. No mesogloeal processes are given oft on the other side of the muscle. The endoderm is continued from the column wall, along both sides of the mesentery; it is slightly narrower here and contains some zooxanthellæ. In some parts deeply stained glandular cells are seen.

The secondary mesenteries are very stout, but reach only a short distance into the cœlenteron. They consist chiefly of a parieto-basilar muscle which appears to be almost fully developed. The retractor muscle is beginning to be formed showing a feathery bunch of muscle folds. In some cases these folds are pressed back owing to the development of large gonads. 
The mesenterial filaments contain large gland cells the contents of which are granular and take stain deeply with borax carmine. There is also a number of nematocysts, some of which are very large ; these are spindle-shaped and do not stain. I am unable to detect the spiral coil in any of the nematocysts of this region. There are also a few nematocysts scattered about. It is very difficult in this specimen to follow the mesenterial filaments, because the gonads tend to push them together into one mass. I can distinguish only one lobe at the tip of each filament and in most cases this is rounded. In the directive mesenteries the lobe is pointed at the tip.

There are two œsophageal grooves, one of which is better developed than the other. The ectoderm is of uniform thickness along the groove ; there is present a wide zone formed by the granules, as in the ectoderm of the column wall. There are no nematocysts or gland cells here, this ectoderm resembling that of the column wall. Beyond the groove the ectoderm is deeply folded, the folds being supported by processes of mesogloea. Gland cells and nematocysts are present on these folds.

The ectoderm of the peristome (Fig. 12) possesses a large number of the gland cells, also a large number of spindle-shaped bodies filled with dark granules, probably empty cases of nematocysts filled with zooxanthellæ. The number of gland cells increases rapidly towards the entrance of the mouth, and the ectoderm in this region is raised into folds supported by mesogloeal processes.

The sphincter muscle (Fig. 11) is situated along a line joining the bases of the acrorhagi. It is a well circumscribed endodermal muscle and seems to be very much like that of Aulactinia gelam figured by Haddon (Plate XXVIII, Fig. 6). In a vertical section of the oral disk it arises from the outer wall near the base of the acrorhagi. It is almost circular, and the surrounding endoderm contains numerous zooxanthellæ. The pedicle is very short and stout, and gives rise to numerous delicate muscle fibres. These are much finer and more numerous than those of $A$. gelam. They branch frequently near their tips, but are not so arborescent as those of $A$. gelam. In a transverse section of the tentacle cut near the base (Fig. 9) the ectoderm contains numerous spindle-shaped and rectangular nematocysts. The spiral coil cannot be distinguished and many gland cells are present. A nerve layer at the base of the ectoderm cells is broad and distinct. The mesogloea consists of a narrow layer of homogeneous structure, except in some parts where it is slightly fibrous. There is a distinct ectodermal muscle, processes of the mesogloea being pushed out on the ectodermal side. There is no indication of an endo- 


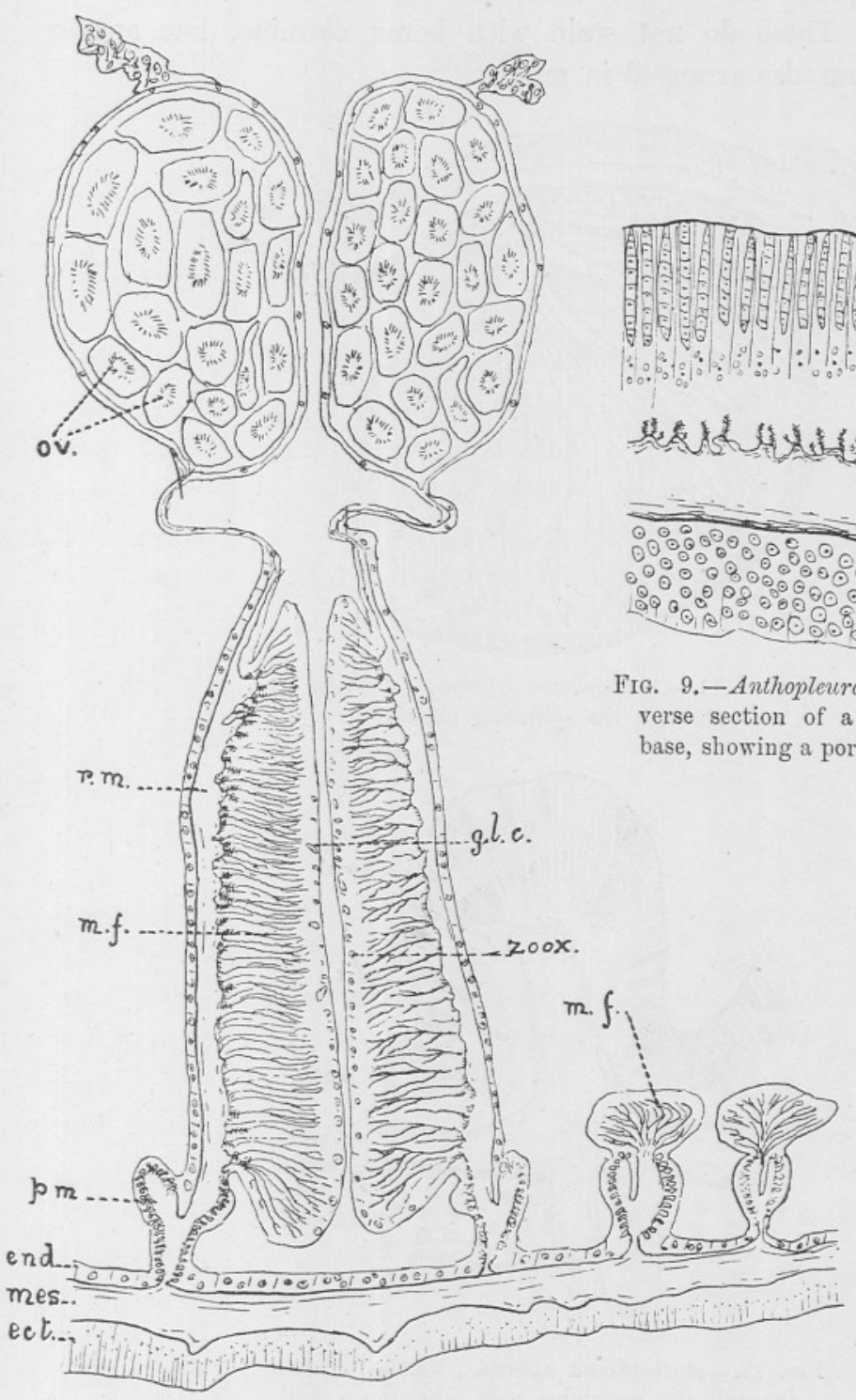

FIG. 10.-Anthopleura alfordi. Transverse section through the column, showing two primary and two secondary mesenteries. 
dermal muscle. The endoderm consists of a spongy layer, which is about the same thickness as the ectoderm, and this is full of colonies of zooxanthellæ. These do not stain with borax carmine, but appear as brownish granules arranged in groups.

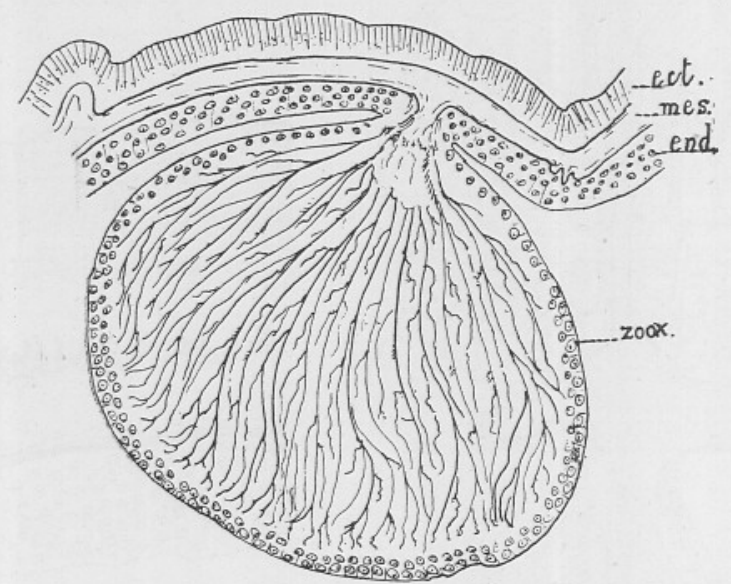

FIG. 11.-Anthopleura alfordi. Section through the sphincter muscle.

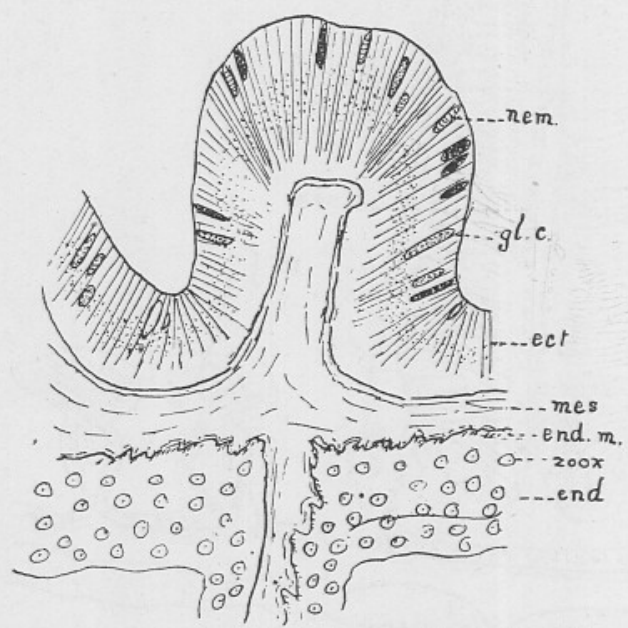

FIG. 12.-Anthopleura alfordi. Vertical section through the peristome wall, showing a fold, and the origin of a mesentery.

In a longitudinal section through a tentacle the ectodermal muscle can be seen as a thin plate of tissue arising from the more deeply stained mesogloea. Lobes and stunted irregular processes penetrate the endoderm. Full-sized"nematocysts are situated near the outer edge of the ectoderm, 
while immature ones are embedded in the middle of the ectodermal tissue and are deeply stained. The older ones are longer and more transparent. The spiral thread could be faintly distinguished in one or two cases ; it is very fine and has a large number of coils. The nematocysts are more numerous at the tip, but they are well developed along the stem.

A. alfordi and $A$. gelam are alike in the following respects: they have more than six pairs of perfect mesenteries ; they possess a well-circumscribed endodermal muscle. I therefore suggest the following as an amended definition of Anthopleura : Cribrinidæ with the upper portion of the column wall provided with longitudinal rows of verrucæ, the lower portion being smooth. The margin forms a more or less distinct collar and the tentacles are polycyclic and entacmæous. More than six pairs of mesenteries of the first cycle are perfect.

\section{Corynactis viridis (Allman, 1846).}

Classification: The following is the classification adopted by Haddon:Tribe : Hexactiniæ (Hertwig, 1882).

Order: Stichodactylinæ (Andres).

Sub-order : Homodactylinæ (Duerden).

Family : Corallimorphidæ (Hertwig).

Genus: Corynactis (Allman).

Species : viridis.

Haddon gives the following definition of the Stichodactylimæ: " Hexactiniæ in which more than one tentacle may communicate with a mesenterial chamber. Usually a peripheral series of one or more cycles can be distinguished from an inner accessory series, the members of which are radially arranged or in groups, and are of different form. The sphincter muscle may be endodermal or absent." Branched tentacles appear quite often.

Duerden has divided the Stichodactylinæ into two sub-orders :-

(a) The Heterodactylinæ in which the tentacles are of two kinds, usually marginal and accessory, and separated by a bare portion of the disk, e.g. Actinotryx, Rhodactis, Heterodactyla.

(b) The Homodactylinæ in which the tentacles are of one kind, simple or complex, and usually follow one another in continuous rows, e.g. Richordea, Corynactis, Stoichactis.

Family: Corallimorphidæ. Stichodactylinæ with a marginal corona of tentacles, and accessory tentacles, arranged in radial series each con- 
sisting of from one to many tentacles. The muscular system is weak throughout the body.

Genus : Corynactis. Corallimorphidæ in which the body-wall is smooth. The tentacles are all knobbed and are arranged in radial series so that more than one communicates with each inter- or intra-mesenterial space. Tentacles and mesenteries tetramerous. Gonidial groove present or absent. Endodermal sphincter very weak. Mesenterial filaments devoid of ciliated streak.

Mesogloea practically homogeneous.

Corynactis viridis (Allman, 1846).

The word Corynactis (Greek=club-stick) refers to the shape of the tentacle.

The emerald-green ring round the capitulum was said to be characteristic of $C$. viridis found in European seas; this green ring was also found on C. carnea (Buenos Ayres) and on C. australis (Port Phillip, Australia).

The specimens I examined were obtained from Plymouth, and were collected on the Breakwater. Some were brightly coloured, green and yellow, others were almost colourless. The following measurements were taken from a preserved specimen from Plymouth :-

$$
\begin{aligned}
\text { Diameter of pedal disk } & =5 \mathrm{~mm} . \\
, \quad, \quad \text { column } & =2.5 \mathrm{~mm} . \\
, \quad, \quad \text { oral disk } & =4 \mathrm{~mm} . \\
\text { Length of } & \text { column }=5.5 \mathrm{~mm} . \\
, \quad, \quad \text { tentacle } & =1 \mathrm{~mm} .
\end{aligned}
$$

The external appearance of $C$. viridis has been described by many of the older writers. In 1884 Andres describes it in L'Attinie in page 266. In the report on Actiniaria dredged by H.M.S. Challenger, 1873-76, Hertwig gives the arrangement of the mesenteries. The first account was written by Allman in the Annals and Magazine of Natural History in 1846. Allman obtained his specimens near low-water mark in the pools left by the retiring tide in Crook Haven, Co. Cork. One of his specimens was a fairly large one measuring $\cdot 5$ inch across the tentacular disk.

In Allman's specimen the colour of the tentacular disk was bright green, except for a circle of radiating brown striæ which surrounded the mouth at a short distance from its margin. The stems of the tentacles were of a sienna colour and their extremities were of a bright rose. He found varieties which were not uncommon, in which the green colour 
except in a narrow ring at the upper margin of the body was entirely replaced by a light flesh colour. Andres' specimen possessed a brilliant metallic iridescence.

In all the paler varieties the animal becomes translucent when expanded, so that the septa and vermiform filaments may be seen through the body-wall. This is evidently an example of albinism. The animal changes its form very often, at one time it will assume the appearance of a slender cylindrical stem, fixed by one extremity and bearing on the other extremity a flattened disk. Sometimes a contraction will take place in the middle of the body so as to cause the animal to present somewhat the appearance of an hour-glass. In assuming its many different forms the stomatodaeum is never everted.

Allman found two concentric rows of tentacles arising near the margin of the disk, but the number and arrangement is variable. They are tubular like the tentacles of other Actiniæ and communicate freely with the interseptal spaces. They are imperforate at the apices, which are very much swollen.

I have examined specimens of $C$. viridis chiefly with the aim of comparing it anatomically with the Australian specimens, which are the only Corynactids well known in this respect.

\section{Anatomy and Histology :-}

The ectoderm of the column wall is fairly spongy in places, in other places it is like that of C. myrcia, described by Duerden, and consists of large unicellular gland cells mingled with narrow supporting cells. The gland cells become swollen near the free surface, where in places they give rise to a clear zone. The contents of these cells are usually clear, and then they do not take stain easily but stand out as highly refractive bodies. In other cases they become deeply stained because the contents are granular.

The nuclei of the ectoderm cells are deeply stained, and as in C. hoplites and $C$. myrcia they are arranged in a zone a little within the middle of the ectoderm layer.

The interior part of the layer forms a clear zone, this marks the position of part of the nervous system. The ectodermal muscle can be distinguished at the base of the ectoderm. The body-wall of the pedal disk is fully expanded, and therefore appears very narrow as compared with that of the column. The ectoderm of the base appears to be one-fourth of the thickness of that of the column wall. In this region the ectodermal muscle is very strong and thick processes of mesogloea can be seen 
projecting into the ectoderm. A layer of foreign material is attached to the outer region of the ectoderm. The mesogloea is a very thin layer, being only one-quarter the thickness of the ectoderm. It becomes deeply stained, is homogeneous, showing no fibrillar structure; and is thicker in places owing to the contraction of the body-wall. In structure it appears to resemble $C$. hoplites and $C$. myrcia, but in $C$. hoplites it is about the same average thickness as the ectoderm. The mesogloea of C. australis is also of considerable thickness.

The endoderm of the column is much narrower than the ectoderm. In this $C$. viridis differs from C. myrcia, where endoderm and ectoderm are of about the same thickness. In $C$. viridis the endoderm becomes thicker near the base: It consists of a spongy mass, and is not so deeply stained on the whole as the ectoderm. In some places there are large oval gland cells which contain a granular substance, these seem to be more numerous in the endoderm than in the ectoderm. The endodermal muscle is very feebly developed, but appears stronger in the base.

There are no zooxanthellæ present in this anemone, nor has their presence been indicated in any of the other members of this genus.

The sphincter muscle (Fig. 13) is endodermal, intermediate between a diffuse and a restricted form, and is stronger than that of either $C$. austratis or $C$. myrcia. The mesogloeal processes are longer than those of $C$. myrcin and are slightly branched. The muscle becomes much stronger towards the upper part of the body. I have failed to recognise the simple circumscribed endodermal portion of the upper part of the sphincter as described and figured by Haddon.

The tentacles were described by Allman in 1846, and he was able to recognise two kinds of nematocysts, the small oval nematocysts which are very numerous and the large stinging cysts. Both kinds have also been found in C. myrcia. The structure of the tentacle (Fig. 15) is very much like that of C. myrcia; the knobs consist almost wholly of deep ectoderm; the mesogloea and endoderm are very thin, and the ectoderm consists of a mass of nematocysts, which are long oval cells with the internal spiral coil showing perfectly. These nematocysts did not stain, but appeared as highly refractive bodies and are also present along the stems of the tentacles and in the ectoderm around the mouth. In C. myrcia the stems of the tentacles are devoid of nematocysts, but they are found in the endoderm near the tip of the tentacles in C. viridis; they have not been mentioned as occurring in the endoderm of any of the other members of this genus. There is a distinct nerve layer at the base of the ectoderm, and that 
of the stem contains nematocysts, but they are not so numerous as on the tip. The nematocysts in the endoderm are not so numerous as those in the ectoderm, and none are present in the endoderm near the base of the tentacle. They are also present in the oval swelling at the tip of the mesenterial filaments. The stomatodaeum is oval in section and the wall is thrown into numerous deep and regular longitudinal folds. As in $C$. myrcia, these folds show a rough approximation to the points of attachment of the complete mesenteries. The ectoderm contains a large

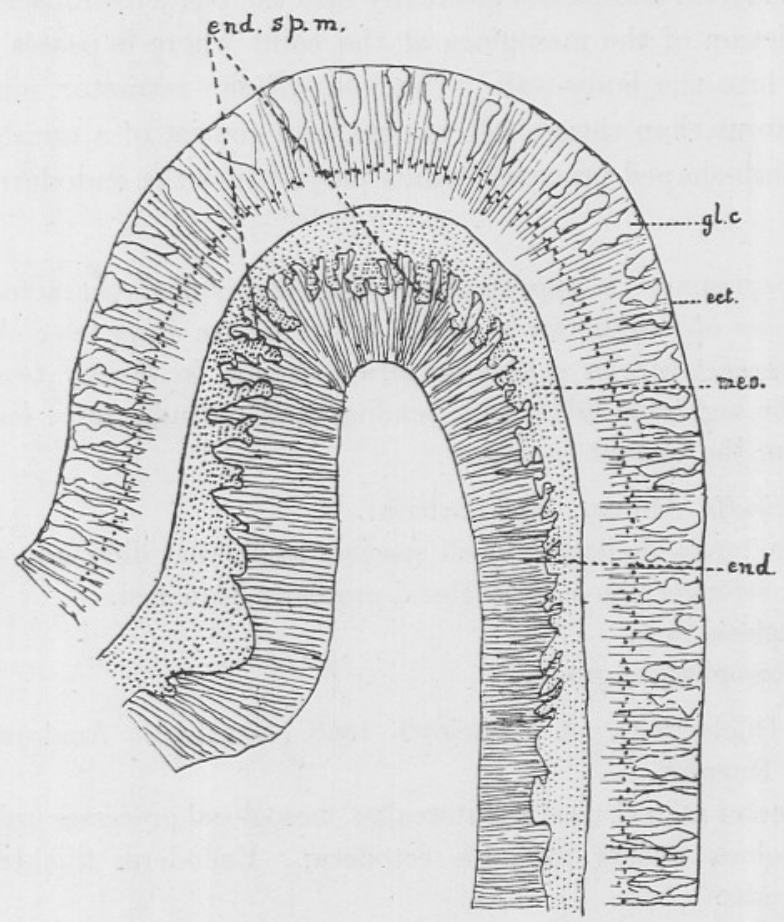

FIG. 13.-Corynactis viridis. Vertical section through the body-wall, showing the sphincter muscle.

number of gland cells, and near the base of this layer there is a quantity of granular material. The mesogloea is thin except at the summit of the folds, where it is thick and gives off small branches which form a strong ectodermal muscle. The endoderm is spongy as in the column wall, it is thicker than the mesogloea and contains large gland cells. One gonidial groove is present, which is not very deep.

The number and arrangement of the mesenteries vary in different specimens. Transverse sections of three different specimens were cut. In one there are 48 mesenteries, some complete and some incomplete, 
including two pairs of directives ; in another there are 36 mesenteries, including one pair of directives ; and in a third there are 46 mesenteries, including two pairs of directives.

There are two cycles of mesenteries (Fig. 14), a primary series, consisting of complete ones, and a secondary series in which they are incomplete. The incomplete mesenteries project for some distance into the cœlenteron; in section they are nearly as broad as the primary mesenteries. The parieto-basilar muscle is stronger than that represented in the figure of $C$. myrcia and passes gradually into the retractor muscles. There is a constriction of the mesogloea at the point where it passes from the mesentery into the body-wall. The folds of the retractor muscles are more numerous than those of $C$. myrcia, and consist of a number of unbranched club-shaped processes which project into the endoderm.

A serial summary is appended showing anatomical characters of the various species of Corynactis in so far as these data have been obtainable. The ordering of tentacles and mesenteries, though frequently tetramerous, appears to be highly variable, and, pending further study, these features are omitted from the present summary.

Corynactis viridis, Allman, 1846 (British).

Sphincter (endodermal in all species) feeble and diffuse in the lower part, stronger above, mesogloeal processes branched.

Mesogloea thin.

One œsophageal groove.

C. myrcia, Duchassaing et Michelotti, 1866 (Jamaica). Anatomical data from Duerden.

Sphincter as in C.viridis, but weaker, mesogloeal processes unbranched. Mesogloea thicker than the ectoderm. Endoderm thicker than in C. viridis.

No œsophageal groove.

C. carnea, Studer, 1878 (Buenos Ayres). Anatomical data from Kwietniewski [23]. Sphincter strong, fibres long and branching; mesogloeal processes branched. Mesogloea about as thick as ectoderm, sometimes thicker.

Two pairs of directives, grooves weak.

C. hoplites, Haddon and Shackleton, 1896 (Torres Straits). Anatomical data from Haddon.

Sphincter strong but diffuse. Mesogloeal processes slightly branched. Mesogloea about as thick as the ectoderm.

Two pairs of directives and one groove. 


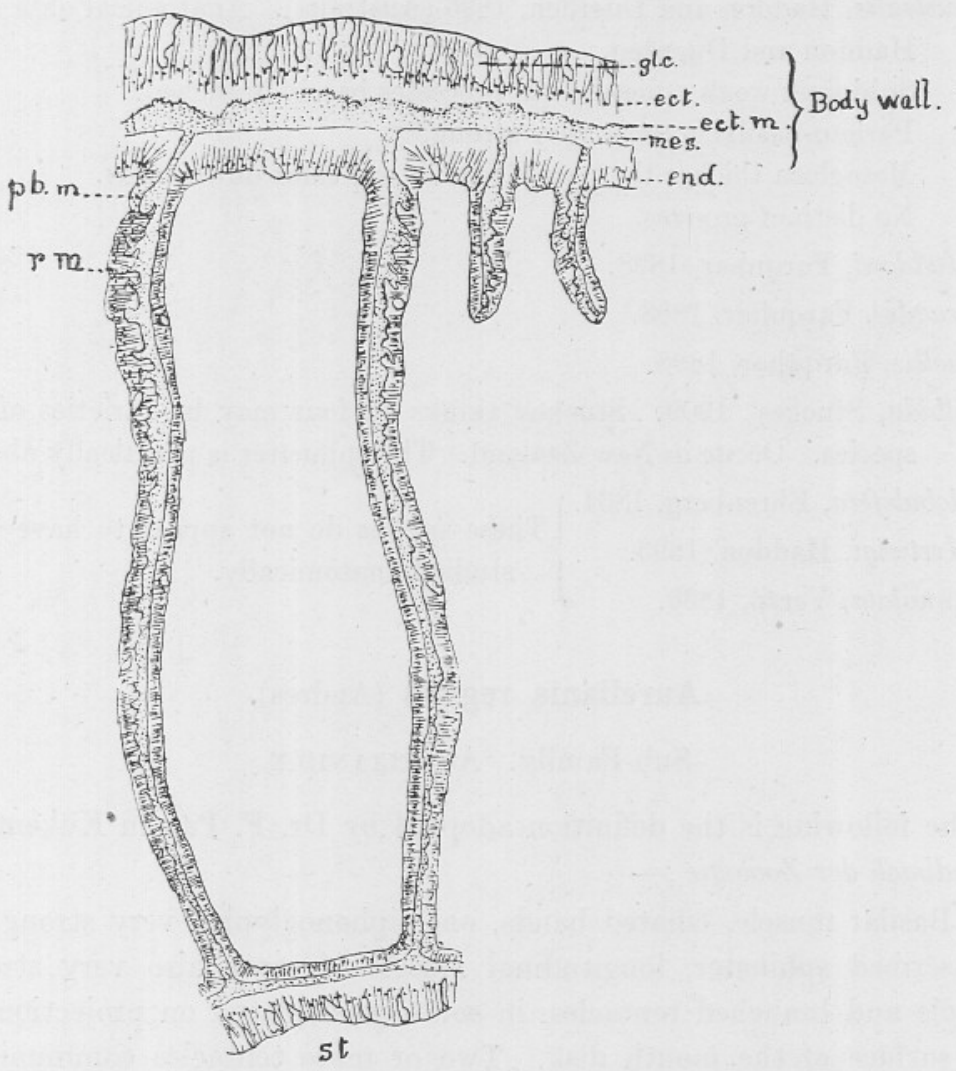

FIG. 14.-Corynactis viridis. Portion of a transverse section of the column in the region of the stomatodaeum, showing one pair of directives and one pair of incomplete mesenteries.

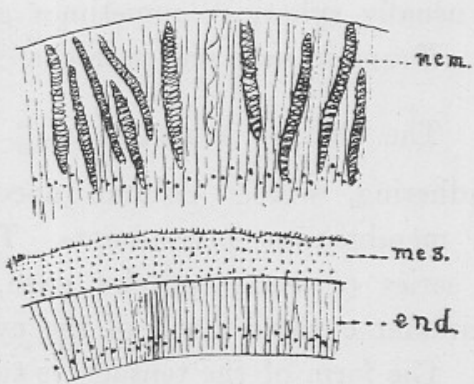

FIG. 15.-Corynactis viridis. Portion of a transverse section of a tentacle, showing the spiral coil in the nematocysts. 
C. australis, Haddon and Duerden, 1896 (Australia). Anatomical data from Haddon and Duerden.

Sphincter weak ; mesogloeal processes barely branched.

Parieto-basilar muscle very strong.

Mesogloea thicker than ectoderm above, thins downwards.

No distinct grooves.

C. Haddoni, Farquhar, 1898.

C. gracilis, Farquhar, 1898.

C. mollis, Farquhar, 1898.

C. albida, Stuckey, 1909. Stuckey thinks all four may be varieties of one species. Occur in New Zealand. The sphincter is practically absent.

C. globulifera, Ehrenberg, 1834 .

C. Hertwigi, Haddon, 1893.

These species do not appear to have been

C. annulata, Verril, 1869 . studied anatomically.

\section{Aureliania regalis (Andres).}

Sub-Family. Aurelianide.

The following is the definition adopted by Dr. F. Pax in Kükenthal, Handbuch der Zoologie :-

"Basilar muscle, ciliated bands, one siphonoglyphe, very strong circumscribed sphincter, longitudinal muscle of septa also very strong. Simple and branched tentacles, in some cases placed on projections of the surface of the mouth disk. Two or more tentacles communicate with each exocoel."

Andres' definition is formed from external characters. "Base adhering, column obconical, not tuberculate, imperforate. Tentacles arranged in radial series, numerous and detached, not simple, but swollen at the apices; the knobs usually spherical, sometimes giving rise to buds. Colour yellowish red. Found in sand and on rocks."

The Genus, Aureliania.

"Form: Base adhering, wide. Column abconical with minute suckers secreting a membranous investment. Tentacles numerous, arranged in radial series of two tentacles each, and at the same time forming four circular cycles. Each of the cycles has a different number of tentacles. The form of the tentacle is tubercular, swollen at the apex, bilobed. Peristome convex, radially grooved. Colours yellowish orange, tinged with vermilion." The above is a translation of the description of the genus Aureliania given by Andres in L'Attinie. He 
regards two species as belonging to this genus, namely $A$. heterocera and A. regalis. A. regalis and A. augusta, Gosse 1860 and Andres 1880, are given as synonyms. Andres in a note states that he found the number of tentacles to agree with that in Gosse's specimen. Since colour is too unreliable a character on which to base species and since the comparative anatomy of $A$. augusta, $A$. regalis, and $A$. heterocera still remains apparently unknown, it seems necessary to retain the name regalis (Andres) for the present, at the same time keeping in mind the possibility of this name being merely a synonym of $A$. augusta (Gosse). The name. regalis is used in France, from which coast the specimen referred to here was obtained. Figs. 4, 5 and 6, in Plate $\mathrm{X}$ in L'Attinie, give an exact reproduction of the form and colour of the specimen when alive.

The following is a translation of Andres' description :-

"Form : Base adhering; spreading, irregular. Column conical below, cylindrical above, smooth, fleshy, not greatly extensible, secreting abundant mucus to form a sheath. Margin turning upwards, minutely crenate, collar deeply grooved. Disk small, smooth. Tentacles retractile, numerous (144) in four cycles $(36+36+36+36)$. [The tentacles may be more than 144 in number; in one specimen I found $168(42+42+$ $42+42$ ) as in $A$. augusta (Gosse).] Each tentacle is short, moniliform and directed outwards. They occupy more than half the periphery of the disk. The form, "monile" (resembling a necklace), is modified in the tentacles of the two external cycles, the swellings are unequal, the proximal is rounded and the apical is prolonged to a point. The peristome is smooth, scarcely striated at the radii. Mouth round, small, not prominent.

"Colour pale rose. Column orange-vermilion with whitish specks. Tentacles of indefinite yellowish colour, transparent with opaque stains and spots. Peristome reddish vermilion. Of the gonidial radii only one is indicated, and this has a whitish line where the radius touches the periphery. Situation in the sand usually covered as far as the disk, but sometimes protruding with part of the column."

Andres examined three individuals, two coincided with the above description, but the third had the peristome spotted.

I took the following measurements from the preserved specimen :-

Diameter of base $=17 \mathrm{~mm}$.

Height of column $=18 \mathrm{~mm}$.

Diameter of oval disk greatly contracted $=9 \mathrm{~mm}$. 
The specimen contained a large amount of mucus, this caused the tissues to contract and become very hard in xylol. The specimen had become very much contracted; for these reasons I am unable to give a full description of the species. The mesenteries are arranged in two cycles, $36+36=72$. The incomplete mesenteries are unevenly developed, some appear as slight projections into the colenteron, others are larger and have produced many muscle folds.

The mesenteries (Fig. 16) possess a very long retractor muscle with a large number of short folds. The curious fact about this muscle is that it faces the intramesenterial space or exocoele instead of the intermesenterial space or endocoele, as is commonly found in Actinians. The longitudinal muscle of the directives faces the intermesenterial space. Near the proximial end of the mesentery lies the parieto-basilar muscle, which arises as a stout projection on the side away from the retractor muscle. It gives off a large number of folds which are longer than those of the retractor muscle, they have a somewhat reticulate appearance when examined under the high power of the microscope. The mesogloea is fibrous and has a number of cavities of irregular shapes. The wall of the œsophagus is raised into a number of lobes. There is one œsophageal groove corresponding to the pair of directive mesenteries present.

The body-wall is strong, the mesogloea forming a thicker layer than the ectoderm. The latter is raised into a large number of folds, each being supported by a process of mesogloea.

This species is extremely rare, and British specimens were not available. One specimen of Auretiania regalis was, however, most kindly sent by Monsieur Louis Fage from the laboratory at Banyuls-sur-Mer, and it is this specimen which has been anatomised and is described above.

\section{INDEX TO LETTERING.}

ect., ectoderm.

ect. m., ectodermal muscle.

end., endoderm.

end. m., endodermal muscle.

end. sp. m., endodermal sphincter muscle.

g., granules.

gl. c., gland cell. mes., mesogloea.

mu., mucus.

n.l., nerve layer.

nem., nematocyst.

pb. m., parieto-basilar muscle.

r.m., retractor muscle.

sph., sphincter.

zoox., zooxanthellæ. 
COMPARATIVE ANATOMY OF SOME BRITISH ACTINIA.

553

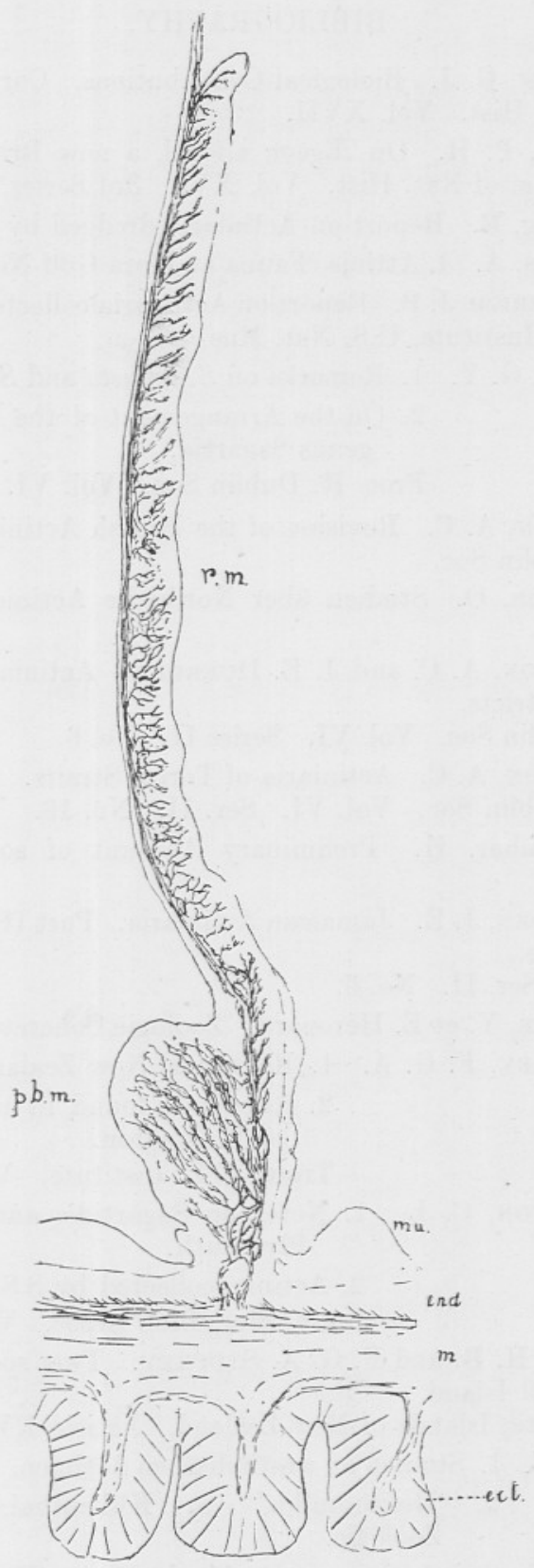

FIG. 16.-Aureliania regales. Transverse section of the column, showing a portion of one of the mesenteries.

NEW SERIES. - VOL. $x$. No. 4. MAY, 1915.

$2 \mathrm{~N}$ 


\section{BIBLIOGRAPHY.}

[1] 1846. Allman, G. J. Biological Contributions. Corynactis. Ann. and Mag. of Nat. Hist. Vol. XVII.

[2] 1865. Gosse, P. H. On Ægeon alfordi, a new British Sea-Anemone, Ann. and Mag. of Nat. Hist. Vol. XVI. 3rd Series. No. XCI.

[3] 1873. Hertwig, R. Report on Actiniaria dredged by H.M.S. Challenger.

[4] 1883. Andres, A. L'Attinie, Fauna et Flora Golf Neapel.

[5] 1887. McMurrich, J. P. Report on Actiniaria collected by the Albatross. Smithsonian Institute, U.S. Nat. Mus.

[6] 1888. Dixon, G. Y. 1. Remarks on S. venusta and S. nivea.

2. On the Arrangement of the mesenteries in the genus Sagartia.

Proc. R. Dublin Soc. Vol. VI.

[8] 1889. Haddon, A. C. Revision of the British Actiniæ. Part I. Proc. R. Dublin Soc.

[9] 1893. Carlgren, O. Studien über Nordische Actinien. Svenska. Ak. Handl.

[10] 1896. Haddon, A. C. and J. E. Duerden. Actiniaria from Australia and other districts.

Proc. R. Dublin Soc. Vol. VI. Series II. No. 6.

[11] 1898. Haddon, A. C. Actiniaria of Torres Straits.

Trans. R. Dublin Soc. Vol. VI. Ser. II. No. 16.

[12] 1898. Farquhar, H. Preliminary Account of some New Zealand Actiniaria.

[13] 1900. Duerden, J. E. Jamaican Actiniaria. Part II. Stichodactylinæ and Zoantheæ.

Vol. VII. Ser. II. No. 6.

[14] 1901. Delage, Y. et E. Hérouard. Zoologie Concrete. Tome II.

[15] 1908. Stuckey, F. G. A. 1. Review of New Zealand Actiniaria.

2. Anemones found in the neighbourhood of Wellington.

Trans. N.Z. Institute. Vol. XLI.

[17] 1908. Walton, C. L. 1. Notes on Sagartidæ and Zoanthidæ from Plymouth. 2. Actiniæ collected by S.S. Huxley. Journ. Mar. Biol. Assoc. Vol. VIII. No. 2.

[19] 1909. KIRк, H. B. and F. G. A. Stuckey. Two species of Actiniaria from Campbell Island.

Sub-Antarctic Islands of New Zealand. Article XVIII.

[20] 1910. PAx, F. 1. Studien an westindischen Actinien. Zool. Jahrb. 1910.

[21] 2. "Hexacorallia," in Kükenthal, Handbuch der Zoologie.

[22] 1912. PAx, F. Les Actinies de la côte du Pérou (Breslau).

Mission de l'Equateur, t. 9, fasc. 4. Paris, Gauthier Villars.

[23] 1896. Kwietniewski, C. R. Revisicn der von Studer gesammelten Actinien. Jenaische Zeitschrift XXX, p. 599. 